\title{
Small hydropower dam site suitability modelling in upper Benue river watershed, Nigeria
}

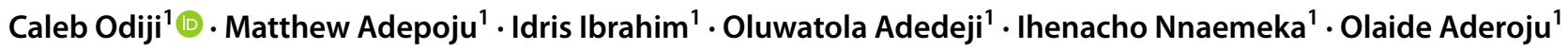

Received: 5 March 2021 / Accepted: 24 June 2021 / Published online: 10 July 2021

(c) The Author(s) 2021

\begin{abstract}
Small hydropower (SHP) is one of the most critical renewable energy that is well adapted to the rural localities in less developed countries across the world. Most rural communities in Nigeria are off the national power grid and are bedevilled by an inconsistent supply of electricity. The one possible panacea to the rural energy crisis is harnessing the terrain and abundant rivers and streams within their domain. This study aimed to identify and select suitable sites for the SHP dam in the upper Benue river watershed. Ten thematic layers, land use, precipitation, geology, soil, slope, elevation, stream power index, topographic wetness index, drainage density, and flow, were integrated with Geographic information system and Analytical hierarchy process. A composite suitability map created revealed that $7.5 \%$ of the watershed is of a very high suitable class, while $17.5 \%$ of the watershed is of a very low suitable class. To select an ideal location, a semi-automatic approach was developed to identify narrow valleys by intersecting contour with stream order and the suitability layer. Eighteen (18) potential dam sites were identified after a query operation was done. The developed method was validated using field data which were correlated with the model output using t-Test; paired two samples for the mean. A strong Pearson correlation of 0.71 between the field data and the semi-automatic approach was observed. The approach offers good prospects for dam site selection. Based on a field survey, the potential dam sites are feasible economically and technically for SHP dam construction that will provide cheap renewable energy to millions of inhabitants in the watershed.
\end{abstract}

Keywords Dam · Small Hydropower · Analytical Hierarchy Process · Watershed · Valley

\section{Introduction}

There are varied definitions according to manufacturers and countries of Small hydropower (SHP). In the USA, a capacity of 30 megawatts (MW) is regarded as small, in Canada, it is up to $50 \mathrm{MW}$, and in Sweden, 'small' refers to up to $1.5 \mathrm{MW}$. Consensually, a capacity of up to $10 \mathrm{MW}$ is regarded as standard by the International union of producers and distributors of electricity (UNIPEDE) (Khare et al. 2019). Hydropower accounts for $71 \%$ supply of renewable energy across the world (Moran et al. 2018) and 16.4\% of the world's electricity (REN21, 2012). The SHP is an important source for the electrification of rural areas and remote locations. A large number of households in developing

Caleb Odiji

odijic@yahoo.com

1 Department of Strategic Space Application, National Space Research and Development Agency, Airport Road, P.M.B. 437, Abuja, Nigeria countries now have electricity via SHP where other technologies would be tough to install (UNIDO 2012). A study conducted by the International energy agency (IEA) noted that Africa, Asia, and Latin America have enormous potential for generating electricity in the rural and remote area through SHP but is still grossly underexploited (IEA 2012). SHP potentials are enormous in many countries in Africa attributed to its physical features; climatic and topographic characteristics. However, the major factor militating against the development of SHP is the lack of complete, up-to-date national inventory of the potential sites for the installation of the SHP systems (Duarte et al. 2010).

The insufficient energy supply to both urban and rural areas in Nigeria constitutes an albatross on any developmental endeavours (Brimmo et al. 2017). The Nigerian Association of Energy Economists (NAEE 2015) indicated that the country is $90 \%$ deficient in the power supply while access to electricity to where $50 \%$ of the population lives is almost zero. Even in on-grid areas, power outages are still a recurrent theme and this has posed serious constraints to 
economic development. Ebhota \& Tabakov, (2018) in their discourse noted that the World Bank reported that Nigeria's population access to the national grid was approximately $55 \%$ and the capacity of the national grid was hovering between 4500-6000 MW for a population of over 190 million considering the untapped potentials.

SHP is one of the potential renewable energy technologies that are suitable and can be very important for the electrification of the rural areas since the bulk of rural environments is rich with rivers, streams, and run-off waters that have the capacities to generate hydroelectric energy. Despite abundant water resources in all states and local government areas in Nigeria, hydropower remains an underutilized resource for electric power generation in Nigeria. In over 150 countries, hydropower plays an important role in providing energy for economic and social growth; hydropower contributes, at least $90 \%$ of the electricity production in 23 countries and at least $50 \%$ in 63 countries (IEA 2012). The SHP is a flexible, renewable technology well suited to local conditions with great prospects for sustainability. If properly harnessed, SHP can alleviate poverty through socioeconomic development, improve the standard of living,

Table 1 Data used

\begin{tabular}{llllll}
\hline Sn & Data & Year & Format & Scale/Resolutionn & Source \\
\hline 1 & Geological map & 2015 & Digital & - & Nigeria geological survey agency \\
2 & Land use land cover & 2018 & Digital & $20 \mathrm{~m}$ & Sentinel-2 \\
3 & Precipitation data & $2000-2020$ & Digital & - & Nigeria metrological agency (NIMET) \\
4 & Soil data & 2013 & Digital & 30 arc-second & HWSD/FAO-UNESCO \\
5 & Existing dams & 2013 & Digital & - & FAO Aquastat \\
6 & SRTM-DEM & 2011 & Digital & $30 \mathrm{~m}$ & https:earthexplorer.usgs.gov \\
\hline
\end{tabular}

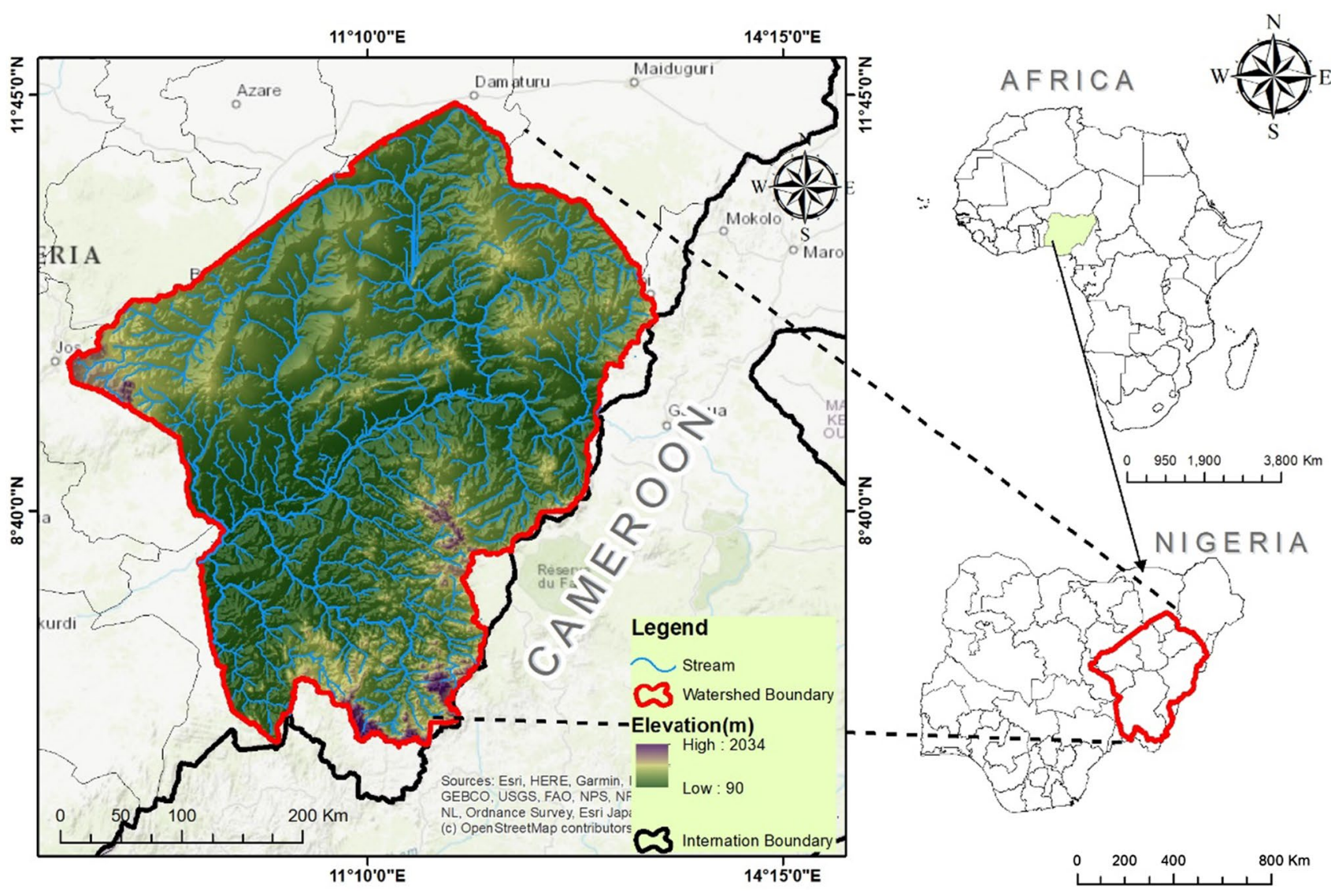

Fig. 1 Location of the upper Benue River watershed 
create employment opportunities, and promote eco-friendly development. Opportunities abound in hydropower scheme development as a viable energy source of electricity, which will curtail and minimize greenhouse gases and emissions into the environment (UNIDO 2012). The upper Benue River watershed is one of the eight hydrological drainage systems in Nigeria with numerous streams and rivers that are yet to be harnessed.

The traditional method of ground surveying for potential hydropower site is expensive, time-consuming, and labourintensive because investigation must be carefully targeted at areas which are most likely to yield useful sites for hydropower development. GIS is a powerful tool for processing spatial information and provide support for renewable energy sources. GIS techniques have gained a prominent role in hydrological modelling. Remote sensing and GIS are modern techniques that are widely used for the assessment of hydropower generation (Connolly et al. 2010). Incorporating GIS has helped in the evaluation of the hydropower potential by integrating different parameters that influence the choice of a suitable site (Punys et al. 2011).

Researchers, academic institutions, NGOs, and others (World Bank, UNIDO, DFID, etc.) have shown the usefulness of remote sensing and GIS in this regard; Othman et al., (2020) used GIS and remote sensing technique to identify suitable dam sites in the Kurdistan Region of Iraq. The study integrated fourteen layers like tectonic zones, distance to active faults, lithology, distance to lineaments, soil type, land cover, distance to towns and cities, hypsometry, slope gradient, average precipitation, stream width, curve number grid, distance to major roads, and distance to villages with AHP and the Weighted sum method (WSM) to determine eleven suitable locations for dam construction. Another study conducted in China adopted the GIS and AHP technique with spatial data like slope, precipitation, geology, soil type, drainage, and land use land cover (Dai 2016). Very few studies have been carried out in Nigeria; Omotayo et al. 2018 in their study made use of Landsat and Digital elevation model (DEM) in selecting

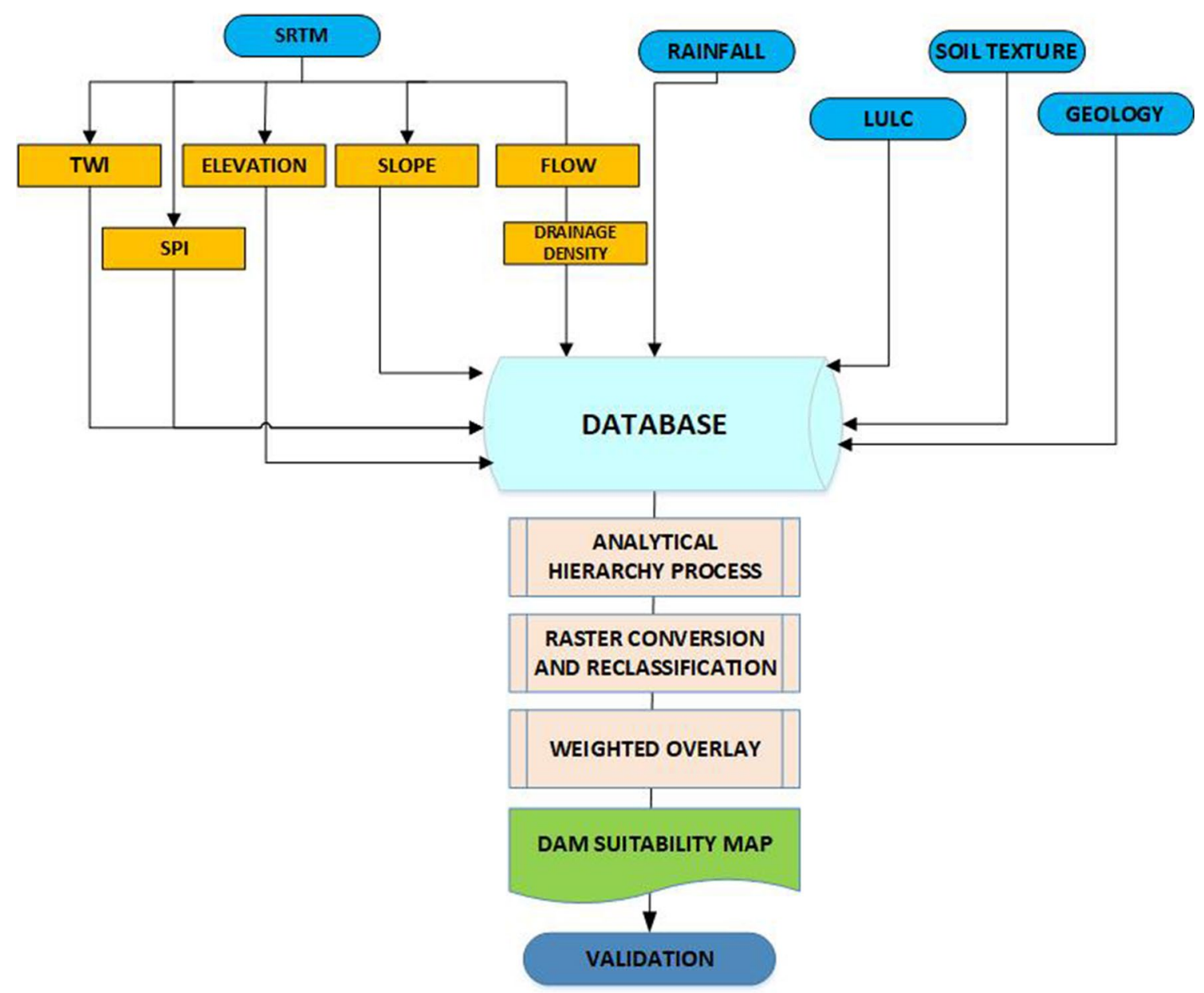

Fig. 2 Methodology flow chart 


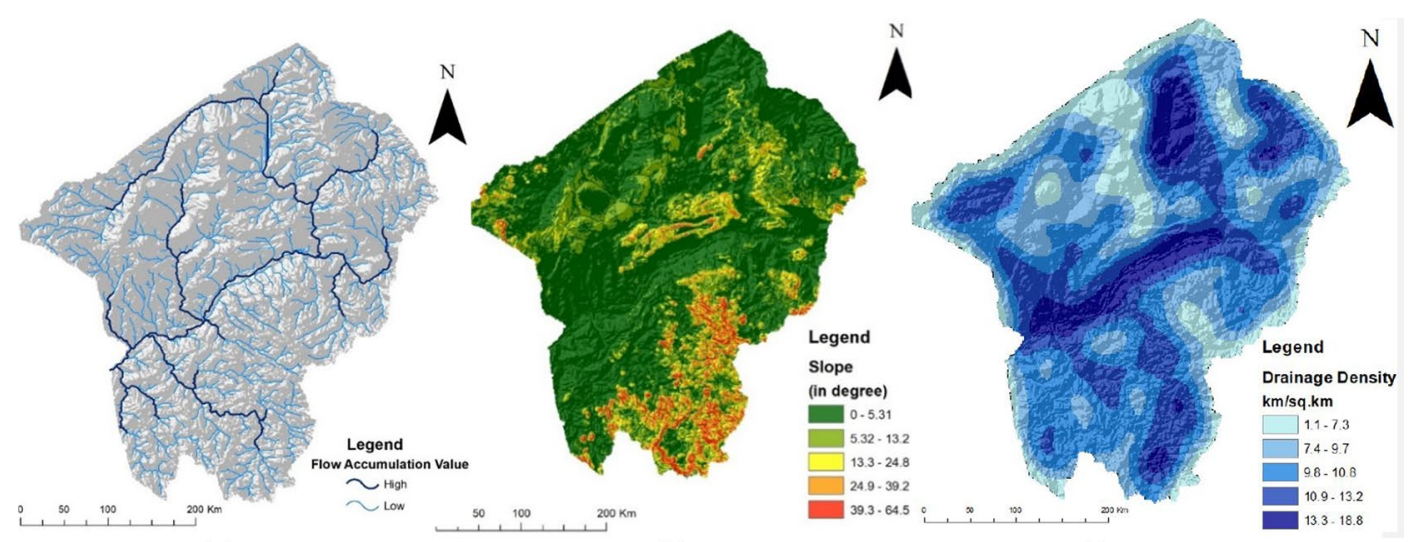

(a)

(b)

(c)

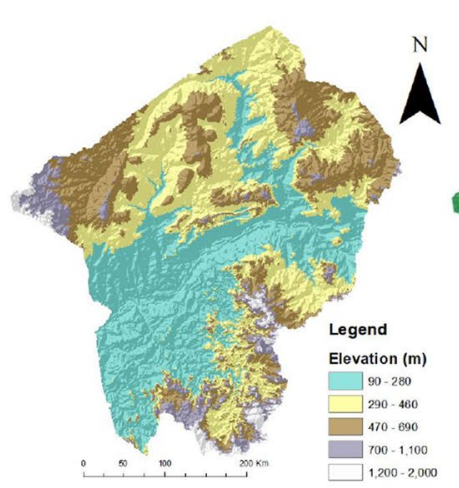

(d)

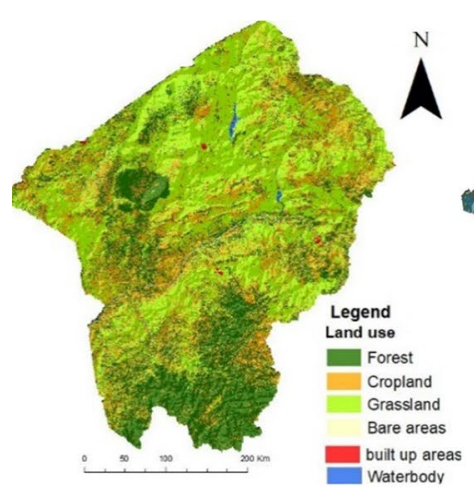

(g)

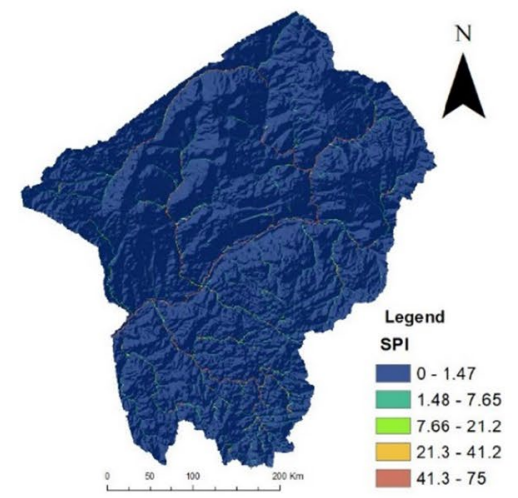

(j)

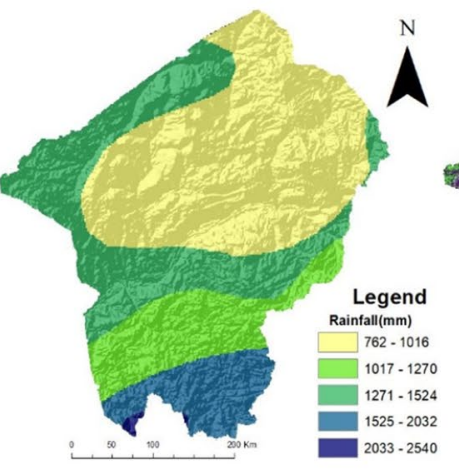

(e)

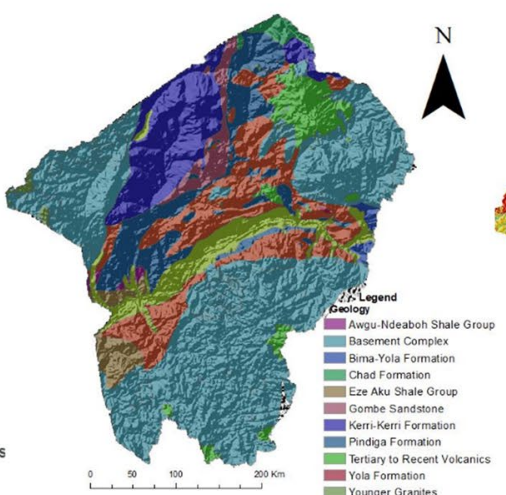

(h)

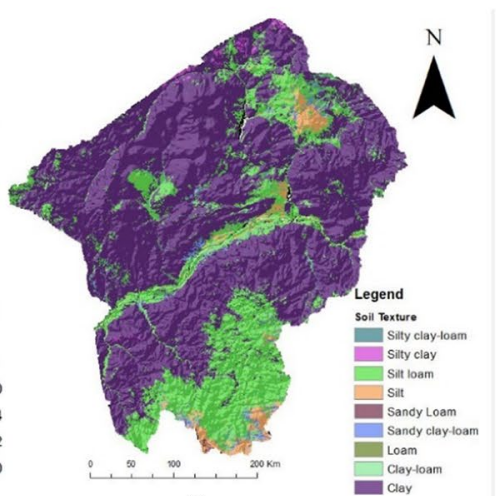

(f)

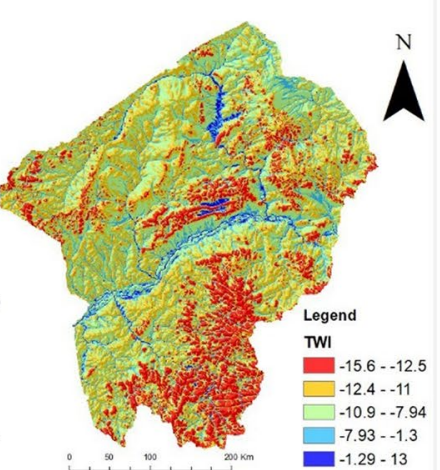

(i) 
4Fig. 3 Criteria for dam site identification (a) flow, (b) slope, (c) drainage density, (d) elevation, (e) soil texture, (f) rainfall, (g) land use land cover, (h) geology, (i) Topographic Wetness Index, (j) Stream Power Index

suitable sites for dams in Ondo and Ekiti states. In this study, it was observed that the data and methods used were grossly inadequate. Ajibade et al. 2020 used the fuzzy logic approach with rainfall, soil, run-off, geology, stream order, and land use land cover to identify potential dam sites in Imo state. Other studies include Yi et al. 2010; Fesalbon \& Blanco 2019; Lalhmingliana \& Saha, 2016; Ahmad \& Verma 2018; Adham et al. 2018. The results of these studies were maps showing the suitability index derived from the aggregation of different parameters. However, most of these studies focused mainly on creating a Dam site suitability map (DSSM) without explicitly elaborating how the potential dam sites were spatially identified and selected.

The study aims to address the identified limitations of the previous studies by developing a semi-automatic approach to identify stream channels with narrow valleys by intersecting contour with stream order. The essence is to improve upon how dam sites can be spatially located by utilizing the topography and morphology of the river valley, especially in a large watershed. To achieve the aim of this study, the following objectives were taken into consideration; (1) to evaluate and map the hydrological and environmental factors, (2) To apply AHP and weighted analysis for creating a suitability index map, and (3) to identify the suitable dam site.

\section{Study area}

The Upper Benue River Watershed covers an area of over $154,328.9 \mathrm{~km}^{2}$. The watershed lies between latitude $6^{\circ} 29^{\prime} \mathrm{N}-11^{\circ} 46^{\prime} \mathrm{N}$ and longitude $8^{\circ} 55^{\prime} \mathrm{E}$ to $13^{\circ} 30^{\prime} \mathrm{E}$. The watershed has an elevation that ranges from 90-2034 m above sea level. The watershed is well-drained by River Benue and its tributaries. The River Benue, the principal river, takes its source in the northern section of the central hills of the Cameroon Republic and enters Nigeria from the east and flows south-west to meet with River Niger. The watershed is marked by two distinct seasons: the rainy season which starts from April to October and the dry season which starts from November to March. The mean annual rainfall is about 700 to $1200 \mathrm{~mm}$, and the mean annual temperature ranges from 24 to $27^{\circ} \mathrm{C}$ (Ishaku et al. 2015). (Fig. 1).

\section{Material and methods}

This section described the various data types used and methods of data processing and analysis performed to identify the potential SHP dam sites in the upper Benue river watershed (Table 1). Figure 2 shows the methodology flow chart of this study illustrating how the data were prepared and processed.

\section{Stream network derivation}

The stream network was generated from DEM by utilizing the ArcGIS 10.5 hydrology tool. The stream network derivation was based on a threshold accumulation value of 500. This means that each cell of the drainage network has a minimum of 500 contributing cells, resulting in a less dense stream network than a lower threshold value depending on the size of the watershed (Chang 2014).

\section{Criteria selection for identification of SHP potential sites}

Site selection involves identifying a location most suitable for the SHP structures. When siting dam engineers look out for the following criteria: morphology of the river valley, topography, geology, and local climate (UNIDO 2019), the criteria chosen for the study were based on a review of works of literature of previous studies (AlRuzouq et al. 2019; Yi et al. 2010; Ajibade et al. 2020; Abushandi and Alatawi, 2015; Larentis et al. 2010; Othman et al. 2020) and hydrological/engineering manuals and availability of data. In identifying potential SHP sites in the watershed, ten (10) criteria were considered: geology, precipitation, slope, soil texture, elevation, land use land cover, drainage density, topographic wetness index (TWI), stream power index (SPI), and regular and abundant flow of water.

Regular and abundant flow of water (flow and discharge) One important criterion for situating a SHP dam is the volume of water that is constantly available throughout the year. A sufficient quantity of water discharged must be available for SHP to work. The direction of flow was determined by finding the direction of the steepest descent from each cell using the DEM. The ArcGIS 10.5 flow direction raster shows the direction water will flow out of each cell of a filled elevation raster. The flow accumulation raster was used to determine the accumulated flow of all cells flowing into each downslope cell, as this indicates a value of the contributing area where rainfall water drains or collects. Areas with higher flow accumulation values are most likely streams, rivers, ponds, or other bodies of water (Korkovelos et al. 2018). This helps in identifying streams in which the flow of water could be above a certain minimum all year round. Figure $3 \mathrm{a}$ shows that the flow accumulation raster with darker symbols represents high flow accumulation values, while the lighter symbols represent low flow accumulation values.

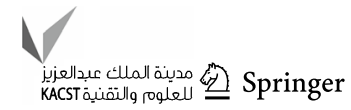


Table 2 Pairwise comparison matrix

Table 3 Normalization

\begin{tabular}{lllllllllll}
\hline & Flow & Rainfall & DD & Geology & Slope & SPI & Soil & TWI & elevation & LULC \\
\hline Flow & 1.00 & 5.00 & 8.00 & 7.00 & 5.00 & 4.00 & 4.00 & 4.00 & 4.00 & 4.00 \\
Rainfall & 0.20 & 1.00 & 4.00 & 3.00 & 2.00 & 3.00 & 3.00 & 5.00 & 3.00 & 3.00 \\
DD & 0.13 & 0.25 & 1.00 & 3.00 & 2.00 & 2.00 & 4.00 & 3.00 & 2.00 & 2.00 \\
Geology & 0.14 & 0.33 & 0.33 & 1.00 & 2.00 & 3.00 & 2.00 & 2.00 & 2.00 & 2.00 \\
Slope & 0.20 & 0.50 & 0.50 & 0.50 & 1.00 & 2.00 & 3.00 & 3.00 & 2.00 & 2.00 \\
SPI & 0.25 & 0.33 & 0.50 & 0.33 & 0.50 & 1.00 & 2.00 & 2.00 & 4.00 & 2.00 \\
Soil & 0.25 & 0.33 & 0.25 & 0.50 & 0.33 & 0.50 & 1.00 & 2.00 & 2.00 & 2.00 \\
TWI & 0.25 & 0.20 & 0.33 & 0.50 & 0.33 & 0.50 & 0.50 & 1.00 & 2.00 & 2.00 \\
elevation & 0.25 & 0.33 & 0.50 & 0.50 & 0.50 & 0.25 & 0.50 & 0.50 & 1.00 & 1.00 \\
LULC & 0.25 & 0.33 & 0.50 & 0.50 & 0.50 & 0.50 & 0.50 & 0.50 & 1.00 & 1.00 \\
\hline
\end{tabular}

\begin{tabular}{llllllllllll}
\hline & Flow & Rainfall & Geology & DD & Slope & SPI & Soil & TWI & Elevation & LULC & Weight \\
\hline Flow & 0.34 & 0.58 & 0.50 & 0.42 & 0.35 & 0.24 & 0.20 & 0.17 & 0.17 & 0.19 & 0.27 \\
Rainfall & 0.07 & 0.12 & 0.25 & 0.18 & 0.14 & 0.18 & 0.15 & 0.22 & 0.13 & 0.14 & 0.21 \\
Geology & 0.04 & 0.03 & 0.06 & 0.18 & 0.14 & 0.12 & 0.20 & 0.13 & 0.09 & 0.10 & 0.11 \\
DD & 0.05 & 0.04 & 0.02 & 0.06 & 0.14 & 0.18 & 0.10 & 0.09 & 0.09 & 0.10 & 0.09 \\
Slope & 0.07 & 0.06 & 0.03 & 0.03 & 0.07 & 0.12 & 0.15 & 0.13 & 0.09 & 0.10 & 0.08 \\
SPI & 0.09 & 0.04 & 0.03 & 0.02 & 0.04 & 0.06 & 0.10 & 0.09 & 0.17 & 0.10 & 0.07 \\
Soil & 0.09 & 0.04 & 0.02 & 0.03 & 0.02 & 0.03 & 0.05 & 0.09 & 0.09 & 0.10 & 0.05 \\
TWI & 0.09 & 0.02 & 0.02 & 0.03 & 0.02 & 0.03 & 0.02 & 0.04 & 0.09 & 0.10 & 0.05 \\
Elevation & 0.09 & 0.04 & 0.03 & 0.03 & 0.04 & 0.01 & 0.02 & 0.02 & 0.04 & 0.05 & 0.04 \\
LULC & 0.09 & 0.04 & 0.03 & 0.03 & 0.04 & 0.03 & 0.02 & 0.02 & 0.04 & 0.05 & 0.03 \\
Total & 1.00 & 1.00 & 1.00 & 1.00 & 1.00 & 1.00 & 1.00 & 1.00 & 1.00 & 1.00 & 1.00 \\
\hline
\end{tabular}

Slope (head) Slope influences the direction and amount of surface run-off in a particular area. When the slope degree increases, the flow velocity in the river also will increase (Masoudian \& Theobald 2011). The slope is a key factor in hydropower generation as a high gradient will generate more power and vice versa. The slope was created from the DEM using the ArcGIS 10.5 surface tool. Figure $3 \mathrm{~b}$ shows that the slope is steep mostly in the south and parts in the north. It is gentle in the central and in the North-Eastern parts of the watershed.

Drainage density (DD) The drainage density is the number of stream lengths per unit area. Areas with high drainage density indicate a high potential for surface run-off and groundwater. High drainage density is suitable for irrigation farming and hydropower generation (Strahler 1957). The stream network was used as input data for the kernel density tool in ArcGIS 10.5 to model the drainage density. The drainage density ranges from 1.1-18.8 km/sq.km (Fig. 3c). The drainage density is high in the North-Eastern part and some areas in the South. It is moderate in the central part of the watershed.
Elevation The elevation of the watershed varies from 90-2032 m with a mean elevation of about $882 \mathrm{~m}$ above sea level. Elevation influences dam location as it affects the velocity of water and flow accumulation (Mura et al. 2018). The elevation of the upper Benue watershed is low in the central and South-Western parts. It is very high in the south and the North-Western part (Fig. 3d).

Soil texture Soil texture is an important factor in locating a suitable site for a dam. Different soils have different infiltration rates, which affects the amount of run-off. Soil texture is crucial for the dam foundation (Roy \& Bhalla, 2017). Figure $3 \mathrm{e}$ shows the upper Benue River watershed is defined by 9 classes of soil type: silty clay loam, silty clay, silty loam, silt, sandy loam, sandy clay loam, loam, and clay. Clay soil is predominant in the study area.

Rainfall The intensity of rainfall impacts significantly the peak discharge of a river. More rainfall more water in the river so a higher discharge. The power potential of any region is determined by the amount, intensity, and distribution of precipitation in the form of rain (Zhao et al. 2019). The rainfall data were interpolated using the Inverse Distance Weight (IDW) method. The rainfall in the watershed 
Table 4 Weight and scores

\begin{tabular}{|c|c|c|c|}
\hline Criteria & Weight & Sub-criteria & Score \\
\hline \multirow{5}{*}{ Flow/discharge } & \multirow[t]{5}{*}{$27 \%$} & Fifth order & 9 \\
\hline & & Fourth order & 7 \\
\hline & & Third order & 5 \\
\hline & & Second order & 4 \\
\hline & & First order & 2 \\
\hline \multirow[t]{5}{*}{ Rainfall(mm) } & \multirow[t]{5}{*}{$21 \%$} & $762-1016$ & 3 \\
\hline & & $1016-1270$ & 5 \\
\hline & & $1270-1524$ & 6 \\
\hline & & 1524-2032 & 7 \\
\hline & & $>2032$ & 9 \\
\hline \multirow[t]{4}{*}{ Geology } & \multirow[t]{4}{*}{$11 \%$} & $\begin{array}{l}\text { pre-Cambrian basement } \\
\text { complex }\end{array}$ & 9 \\
\hline & & $\begin{array}{l}\text { undifferentiated sedimentary } \\
\text { rock }\end{array}$ & 7 \\
\hline & & Sandstones & 5 \\
\hline & & chad formation & 3 \\
\hline \multirow{5}{*}{$\begin{array}{l}\text { Drainage } \\
\text { density }(\mathrm{km} / \\
\text { sq.km) }\end{array}$} & \multirow[t]{5}{*}{$9 \%$} & $1.1-7.3$ & 2 \\
\hline & & $7.4-9.7$ & 3 \\
\hline & & $9.8-10.8$ & 5 \\
\hline & & $10.9-13.2$ & 7 \\
\hline & & $13.2-18.8$ & 9 \\
\hline \multirow[t]{5}{*}{ Slope(degree) } & \multirow[t]{5}{*}{$8 \%$} & $<5$ & 9 \\
\hline & & $5.32-13.2$ & 7 \\
\hline & & $13.3-24.8$ & 5 \\
\hline & & $24.9-39.2$ & 3 \\
\hline & & $>39.2$ & 2 \\
\hline \multirow[t]{5}{*}{ SPI } & \multirow[t]{5}{*}{$7 \%$} & $0-0.29$ & 2 \\
\hline & & $0.29-0.308$ & 4 \\
\hline & & $309-0.598$ & 6 \\
\hline & & $0.599-5.1$ & 7 \\
\hline & & $5.11-75$ & 9 \\
\hline \multirow[t]{5}{*}{ Soil } & \multirow[t]{5}{*}{$5 \%$} & Loam & 1 \\
\hline & & Sandy loam & 4 \\
\hline & & Sandy clay loam & 6 \\
\hline & & clay & 7 \\
\hline & & silt & 9 \\
\hline \multirow[t]{5}{*}{ TWI } & \multirow[t]{5}{*}{$5 \%$} & $-15.6--12.5$ & 3 \\
\hline & & $-12.4--11$ & 5 \\
\hline & & $-10.9--7.94$ & 6 \\
\hline & & $-7.93--1.3$ & 8 \\
\hline & & $-9.2--12.1$ & 9 \\
\hline \multirow[t]{5}{*}{ Elevation } & \multirow[t]{5}{*}{$4 \%$} & 90-295 & 9 \\
\hline & & $295-494$ & 8 \\
\hline & & 494-766 & 5 \\
\hline & & $766-1192$ & 3 \\
\hline & & $1192-1964$ & 2 \\
\hline
\end{tabular}

Table 4 (continued)

\begin{tabular}{llll}
\hline Criteria & Weight & Sub-criteria & Score \\
\hline Land cover & $3 \%$ & Built-up & Restricted \\
& Forest & 1 \\
& Cropland & 1 \\
& Grassland & 2 \\
& Water body & 7 \\
& Bare surface & 9 \\
\hline
\end{tabular}

varies from 762 to $2540 \mathrm{~mm}$. It is very high in the Southern part, however; it ranges from moderate to low in the Northern part (Fig. 3f).

\section{Land use land cover}

Land use land cover affects surface roughness, infiltration rates, and annual peak flow and run-off in a watershed (Samaniego \& Bárdossy 2006). Figure $3 \mathrm{~g}$ shows that $39.2 \%$ of the watershed is made up of grassland, forest accounted for $31.6 \%$, while Built-up and bare surface/cropland constitute $0.15 \%$ and $1.6 \%$, respectively. Water bodies occupy $0.803 \%$ of the watershed.

\section{Geology}

Geology beneath the dam is a very important factor that integrates the base of the dam wall. Hard rock is preferable geology for dams (Strahler 1957). The rock structure on which the dam will be constructed should be strong enough to sustain the weight of the dam and water impoundment. The geology of the watershed was reclassified into four distinct formations. The basement complex rock is the predominant geology found largely in the south and some part in the north. The igneous and metamorphic rocks of pre-Cambrian age are present in the northern part (Fig. 3h).

\section{Topographic wetness index (TWI)}

The TWI is used as a proxy to indicate areas with potential for run-off. The TWI is used to determine the force of water flow and accumulation. It was proposed by Beven and Kirkby,(1979). The TWI of the watershed was derived from DEM using a raster calculator. Higher values are wetter, and the lower values are drier. TWI is calculated as;

Topographic Wetness Index $=\operatorname{in}\left(\frac{\text { Catchment Area }}{\tan B}\right)$

where $\tan \mathrm{B}=$ slope in degree. 
Fig. 4 Head drop: inset: profile sketch of the river channel at $100 \mathrm{~m}$
Fig. 5 Suitability map for SHP dams
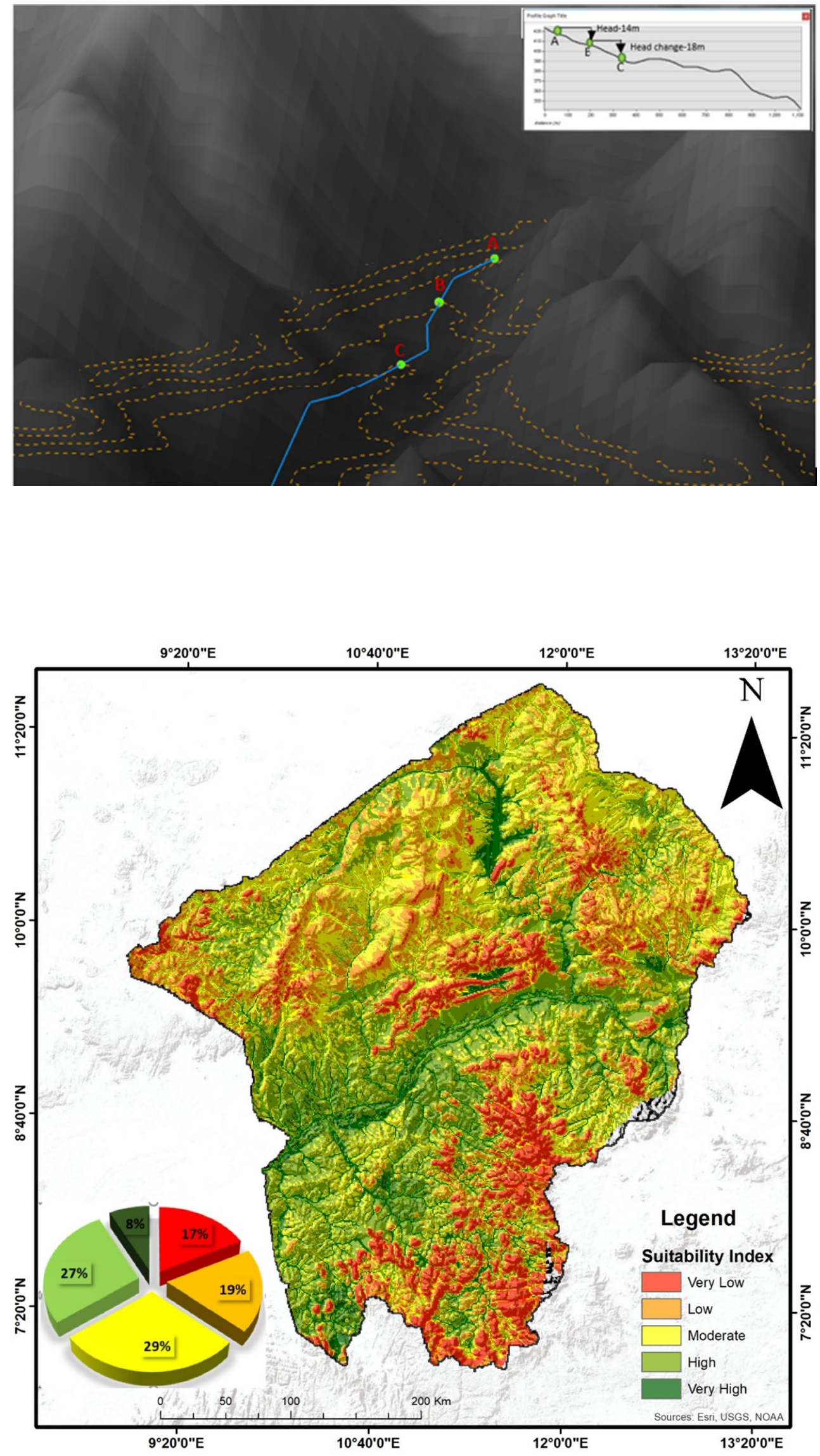


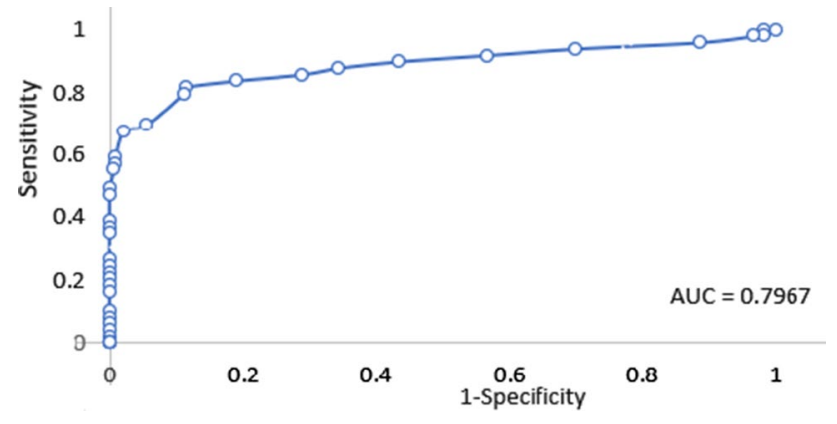

Fig. 6 ROC curve for the suitability map for SHP dam

The TWI ranged from -15.5 to 21.1 in the watershed. The TWI is high in the centre particularly along the main river channel and the North. It is low in the South (Fig. 3i).

\section{Stream power index (SPI)}

The SPI is a measure of the erosive power of flowing water. SPI is calculated based upon the slope and contributing area. The SPI was derived from DEM using a raster calculator. According to (Moore 1972), SPI can be calculated using the following equation;

Stream Power Index $=$ catchment $\operatorname{area} \mathrm{x} \tan B$

where $\tan \mathrm{B}=$ slope in degree.

The SPI ranged from 0.26 to 75 in the watershed (Fig. 3j).

\section{Determination of Criteria Weights using AHP}

One of the commonly used multi-criteria decision-making (MCDM) approaches is AHP. Saaty (1977) introduced AHP and has been used by many researchers in the analysis of site suitability for a dam. In this study, a $10 \times 10$ pairwise comparison matrix was constructed where each criterion was ranked against the other by assigning a relative value between 1 and 9 based on the opinion of experts, engineers, hydrologists, and a review of related works of literature and textbooks (Table 2).

Table 3 is the normalization matrix derived by dividing the column elements of the matrix by the sum of each column. The row elements in the obtained matrix are summed, and the total value is divided by the number of elements in the row.

The consistency ratio of the pairwise comparison judgments was calculated as;

Max. Eigenvalue $(\lambda \max )=10.68, n=10$.

$C I=\frac{\lambda \max -n}{C(-1}=0.0755$.

$C R=\frac{C l^{n-1}}{R I}=\frac{0.0755}{1.49}=0.051$

$C R=0.051<0.10($ Acceptable $)$

The consistency ratio of the pairwise comparison judgments was; 0.051 .

\section{Weight assignment to criteria}

Sub-criteria were ranked within the range of $0-9$, in line with experts' opinions (Table 4). High scores were assigned to the sub-criteria that have a major influence, while lower scores were given to sub-criteria whose influence is marginal.

\section{Reclassification and weighted overlay}

The criteria were resampled to a common cell value and reclassified and overlaid using the Weighted Overlay. The output generated was grouped into five classes: very high, high, moderate, low, and very low.

Table 5 Characteristics of the existing dams

\begin{tabular}{|c|c|c|c|c|c|c|c|}
\hline $\mathrm{s} / \mathrm{n}$ & Name of Dams & Location & Type of dam & Elevation(m) & Purpose & Suitability level & Stream order \\
\hline 1 & Waya & $\begin{array}{l}10^{\circ} 0^{\prime} 34^{\prime \prime} \mathrm{E} \\
10^{\circ} 21^{\prime} 33^{\prime \prime} \mathrm{N}\end{array}$ & Gravity & 490 & Irrigation and power generation & High & 1 \\
\hline 2 & Dadin Kowa & $\begin{array}{l}11^{\circ} 29^{\prime} 3 " \mathrm{E} \\
10^{\circ} 19^{\prime} 31^{\prime \prime N}\end{array}$ & Reservoir & 250 & Irrigation and power generation & High & 3 \\
\hline 3 & Biu & $\begin{array}{l}12^{\circ} 6^{\prime} 111^{\prime \prime} \mathrm{E} \\
10^{\circ} 38^{\prime} 12^{\prime \prime} \mathrm{N}\end{array}$ & Gravity & 611 & Irrigation & Moderate & 1 \\
\hline 4 & Balanga & $\begin{array}{l}11^{\circ} 35^{\prime} 44^{\prime \prime} \mathrm{E} \\
9^{\circ} 55^{\prime} 43 \mathrm{~N}\end{array}$ & Gravity & 302 & Irrigation & Moderate & 2 \\
\hline 5 & Kiri & $\begin{array}{l}12^{\circ} 7^{\prime} 41^{\prime \prime} \mathrm{E} \\
10^{\circ} 9^{\prime} 40^{\prime \prime} \mathrm{N}\end{array}$ & Reservoir & 163 & Irrigation and power generation & High & 5 \\
\hline 6 & Ankwil & $\begin{array}{l}8^{\circ} 58^{\prime} 24^{\prime \prime} \mathrm{E} \\
9^{\circ} 45^{\prime} 53^{\prime \prime N}\end{array}$ & Reservoir & 1235 & Irrigation and water supply & Low & 1 \\
\hline 7 & Lantang & $\begin{array}{l}9^{\circ} 52^{\prime} 59^{\prime \prime} \mathrm{E} \\
9^{\circ} 13^{\prime} 00^{\prime \prime} \mathrm{N}\end{array}$ & Gravity & 273 & Water supply & High & 2 \\
\hline
\end{tabular}


Fig. 7 Distribution of existing dams on the suitability map

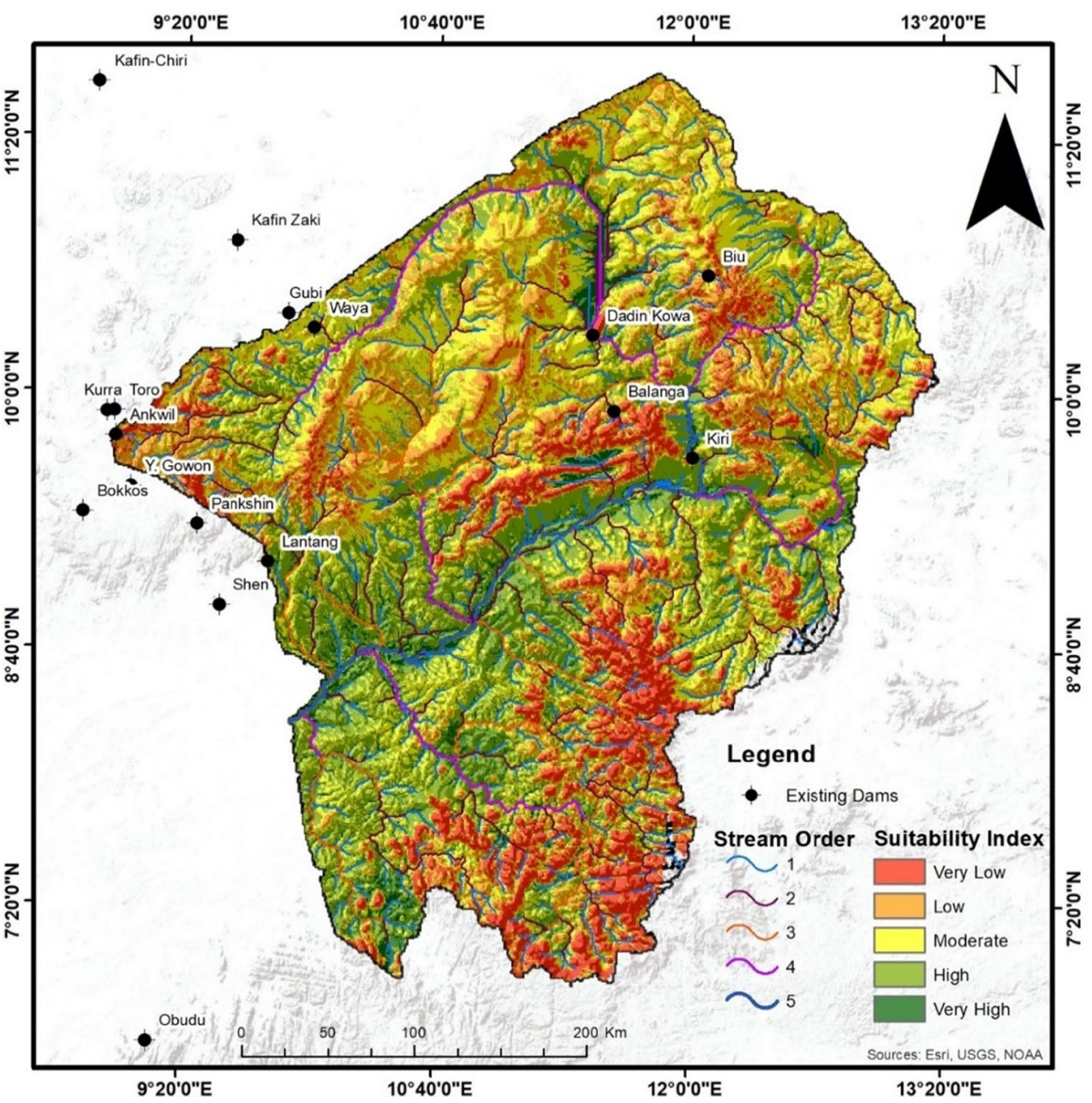

\section{Dam site identification}

The proposed dam sites were chosen based on, suitability index, the natural head (difference in height in the stream channel), and contour. The natural head has a critical influence on the performance of the run-of-river (gravity) type of SHP. Most small hydropower sites are categorized as low or high head (Yamato \& Shiibashi 2012). The high head is usually suitable for the run-of-river type of SHP because it can produce large amounts of power with very modest flows and therefore require small structures (Korkovelos et al. 2018). The cross-sectional profile of the river channel was done to determine the natural head from the upstream to the downstream at every $100 \mathrm{~m}$ interval (Fig. 4). The morphology of the river valley plays a vital role in the choice of dam sites. For SHP, a narrow valley is ideal; if a river valley is narrow, only a small dam is required which means the cost of dam construction or diversion system will be less. On the other hand, if the channel is wide, a bigger dam is necessary which means the construction cost will be very high (Becue et al. 2002). Contours are good visualization of the topography, and this was used to identify the valley based on the closeness of contours forming a V-shape valley (Padmavathy et al. 1993; Adham et al. 2018).

Identifying narrow valleys in this vast study area manually is very cumbersome; hence, a semi-automatic approach was developed. Firstly, a $200 \mathrm{~m}$ buffer was created around the streams (Othman et al. 2020). The buffered region was overlaid on the suitability index map and clipped. This is to ensure that the search radius is within $200 \mathrm{~m}$. Secondly, an intersect sub-tool in the analysis toolbox in ArcGIS 10.5 was used to intersect the 100-m interval contour with stream orders and suitability index. Thirdly, the point and line output features class were generated with attribute values from the input features copied to the output. Lastly, with the database created, structure query language (SQL) was implemented to search for the narrow valley.

\section{Model validation}

For this study, the area under the curve (AUC) of the Receiver operating characteristics (ROC) was used to validate the performance of the prediction (Rahmati et al. 2019; Choubin et al. 2019). This was done by comparing 


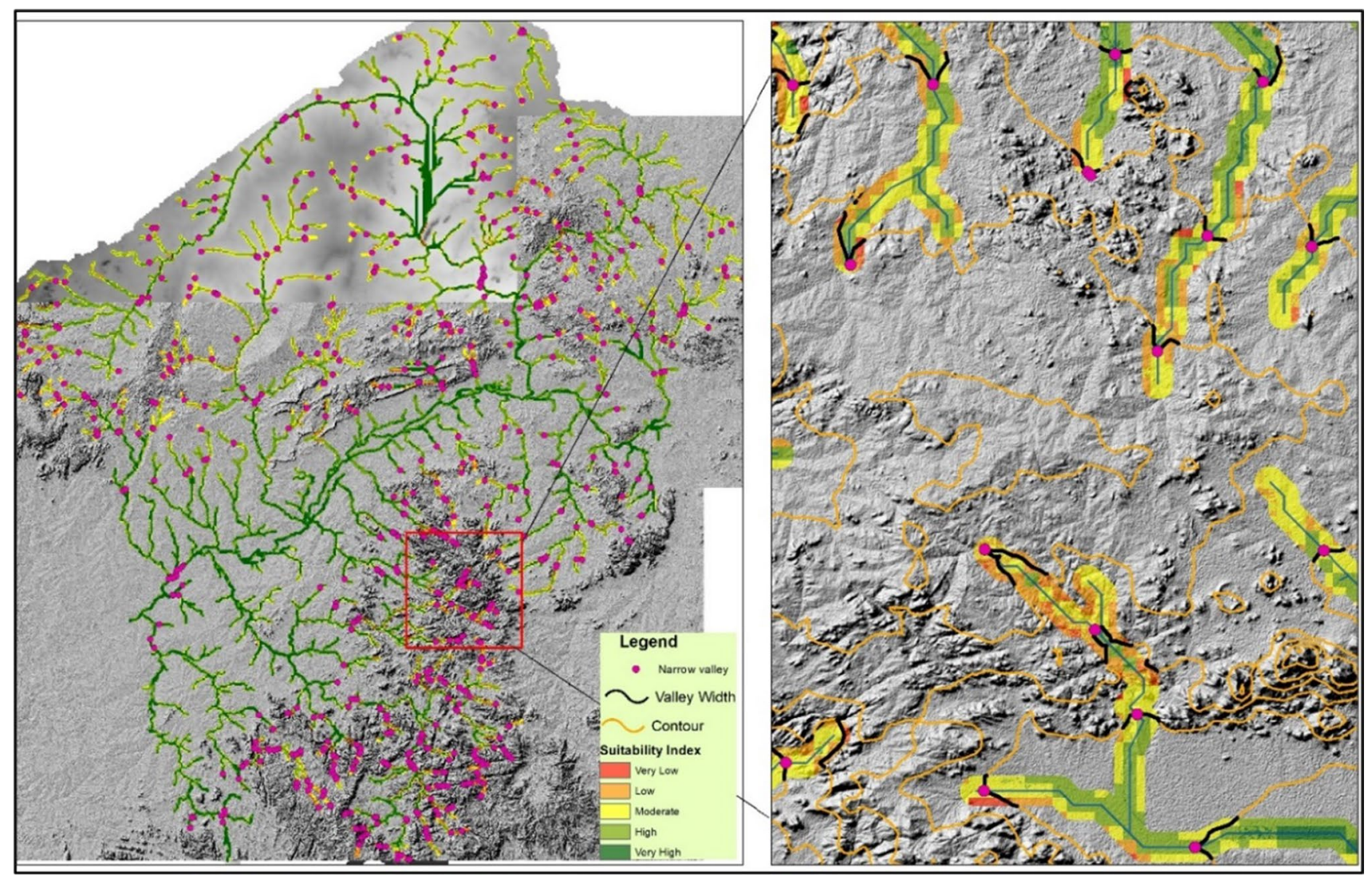

Fig. 8 Numerous points and lines indicate valley width when the contour is intersected with the river and the suitability index

the predicted result with historical data of surveyed potential sites (Supplementary Material, Figure S1). Sample points were generated and overlaid on the historical and predicted data. ArcGIS 10.5 extract to multivalues to point tool was to used to extract cell values of predicted and historical data to the sample points after which it was converted to Excel. Microsoft Excel was used to construct the ROC curve. The values of AUC vary from $0-1$. Values close to 1 indicate better performance, while values close to 0.5 indicate random prediction.

\section{Results and discussion}

\section{Dam suitability index mapping}

With the integration of all criteria, a composite suitability layer was produced and categorized into five classes. As shown in Fig. 5, it was determined that the very high suitable class makes up $11,111.2 \mathrm{~km}^{2}(7.5 \%)$ of the watershed. The very high suitable class is the least located majorly in the stream channel in the north and centre, while $40,327.2 \mathrm{~km}^{2}$ $(27.4 \%)$ of the high suitable class is located in the central and the southern part of the watershed. The moderately suitable class accounts for $42,132.0 \mathrm{~km}^{2}(28.6 \%)$, and it is the most dominant class spread proportionately across the watershed. The low suitable class makes up $27,533.9 \mathrm{~km}^{2}$ (18.5\%) of the watershed occurring mostly in areas with very high elevation. The very low suitable region occupies $25,729.33 \mathrm{~km}^{2}(17.5 \%)$ located in the southern part particularly on mountain ranges and peaks. By comparing the suitability map with the various thematic layers, it was discovered that the effective factors responsible for areas having a very high and high suitable class were; high drainage density, high TWI and SPI, low vegetation cover, moderate slope, moderate elevation, and rainfall along with basement complex rock. The most influencing factors for the moderately suitable class include rainfall and relatively high elevation with a slightly steep slope and moderate drainage density. Areas with very low and low suitability are located in areas with low rainfall, steep slope, weak geology, and high elevation along with low drainage density. 


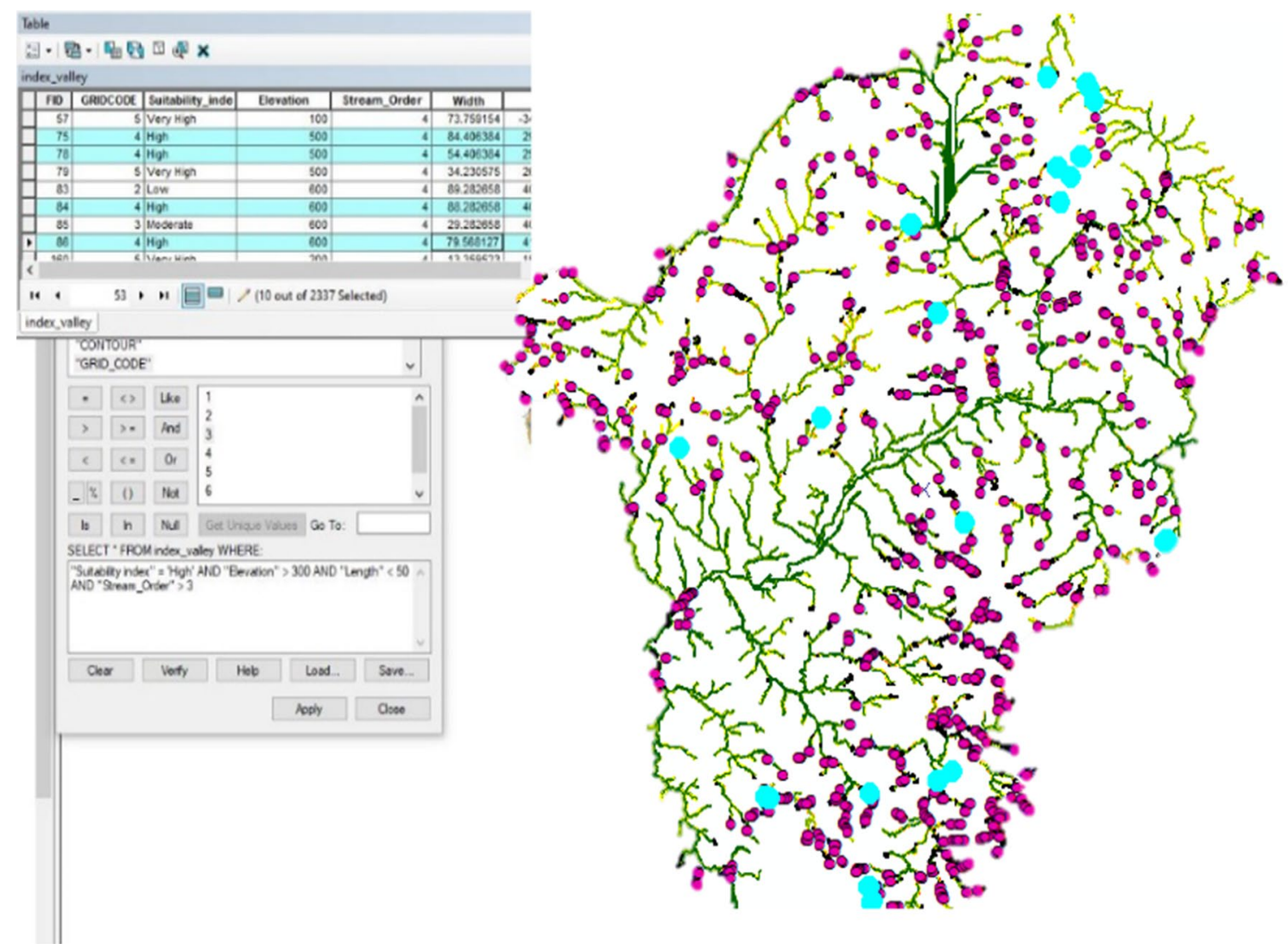

Fig. 9 Query operation to search and display valley width

\section{Validation of suitability model}

The effectiveness of the prediction was analysed by comparing the model with historical data of surveyed potential sites investigated using the ROC curve. The result revealed that the value of AUC was 79.67\%, indicating that the performance of the model was good and it also shows a strong correlation between the suitability map and the historical data (Fig. 6).

The accuracy of the model output was further validated with the existing dams in the Watershed. Geospatial distribution and characterization of existing hydropower dams are important in selecting the optimal locations of the proposed SHP dams.

There are seven existing dams in the watershed all of which are situated in areas where they were deemed suitable (Table 5). Four dams are dual-purpose, two dams for irrigation purposes, one dam for water supply, and one dam for irrigation and water supply (Supplementary Material, Figure S2). Furthermore, four existing dams representing $57.17 \%$ are located in areas where the level of suitability is high, two dams representing $28.57 \%$ are located in moderately suitable areas, and one dam representing $10 \%$ is of low suitability. Based on stream order, three dams are located on the first stream order, two dams on the second- and third-stream order, respectively, and one dam on the fifth order (Fig. 7).

\section{Dam sites selection}

Essentially, dams are linked with valleys and are not constructed on flat ground. This study proposed a semi-automatic approach that can help to identify an ideal site with a good head drop and a narrow valley. Gravity dams are typically appropriate in a narrow valley. The result of the contour intersection with rivers and suitability index map created numerous point and line features indicative of narrow valleys (Fig. 8).

A total of 636 narrow widths were identified spread across the entire watershed. Attributes were automatically assigned to the point features allowing query operation to be implemented using SQL command. For example, spatial query operation was done to search and display valleys using this expression: SELECT*FROM proposed_damsite WHERE stream_order $>3$ and width $<200 m$ and elevation $<400 m$ and suitability level = "very high" and "high" (Fig. 9).

Based on the SQL command, eighteen dam locations were identified and proposed across the watershed (Fig. 10). 
Fig. 10 Locations of potential small hydropower sites in Upper Benue Watershed

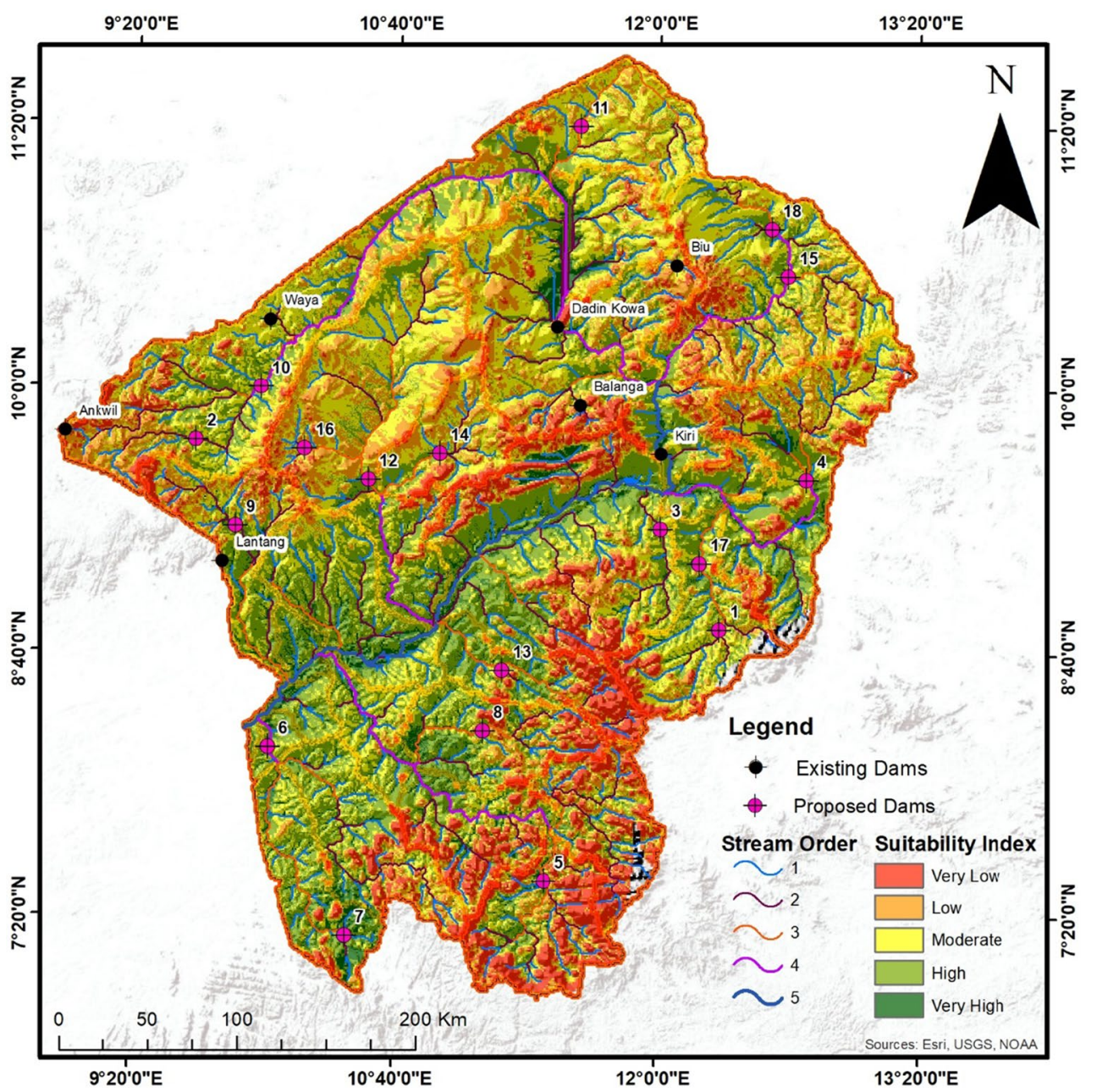

The selected dam sites are located on the third- and fourthorder streams (adequate minimum flow) which fall in the very high and high suitable regions and good head drop (slope). These proposed sites have high drainage density, good geological structure, moderate to very high rainfall, and high SPI. The dam sites have narrow valleys located between the hill and other landforms. The cross-sectional profile of all dam sites was constructed to show the height and width characteristics of the proposed dam locations (Fig. 11). The V-shape valley at each of the dam sites will make for good embarkment for the dam structure and water diversion system and by extension reduce the cost of construction and environmental impact (Abushand, and Alatawi 2015).

\section{Evaluation of semi-automatic model versus field survey}

Due to irregular temporal, and spatial resolution of the dataset used, a field survey was carried out to validate the result of the semi-automatic approach for valley width identification. A direct field survey and measurement of five of the potential dam sites was conducted (Supplementary Material, Figure S3). Out of 18 proposed dam sites, the valley widths of five dam sites (\#2, \#6, \#8, \#10, and \#13) were sampled and measured with a handheld GPS and then compared with the result of the model output on the desktop using t-Test; paired two samples for the mean. The other dam sites were inaccessible due to the remoteness of the location. The result of the t-Test between the field survey and the semi-automatic approach is presented in Table 6 . The result shows that the t-statistic is greater than the critical statistic, indicating that there is a significant difference between the field survey and the semi-automatic approach. The semi-automatic approach underestimated the field survey in all the dam sites ranging from $7.1 \%-33.1 \%$. The result also shows a strong Pearson correlation of 0.71 between the field survey and the semiautomatic approach. The semi-automatic approach offers a bright prospect that can be improved upon using a very high-resolution dataset. 

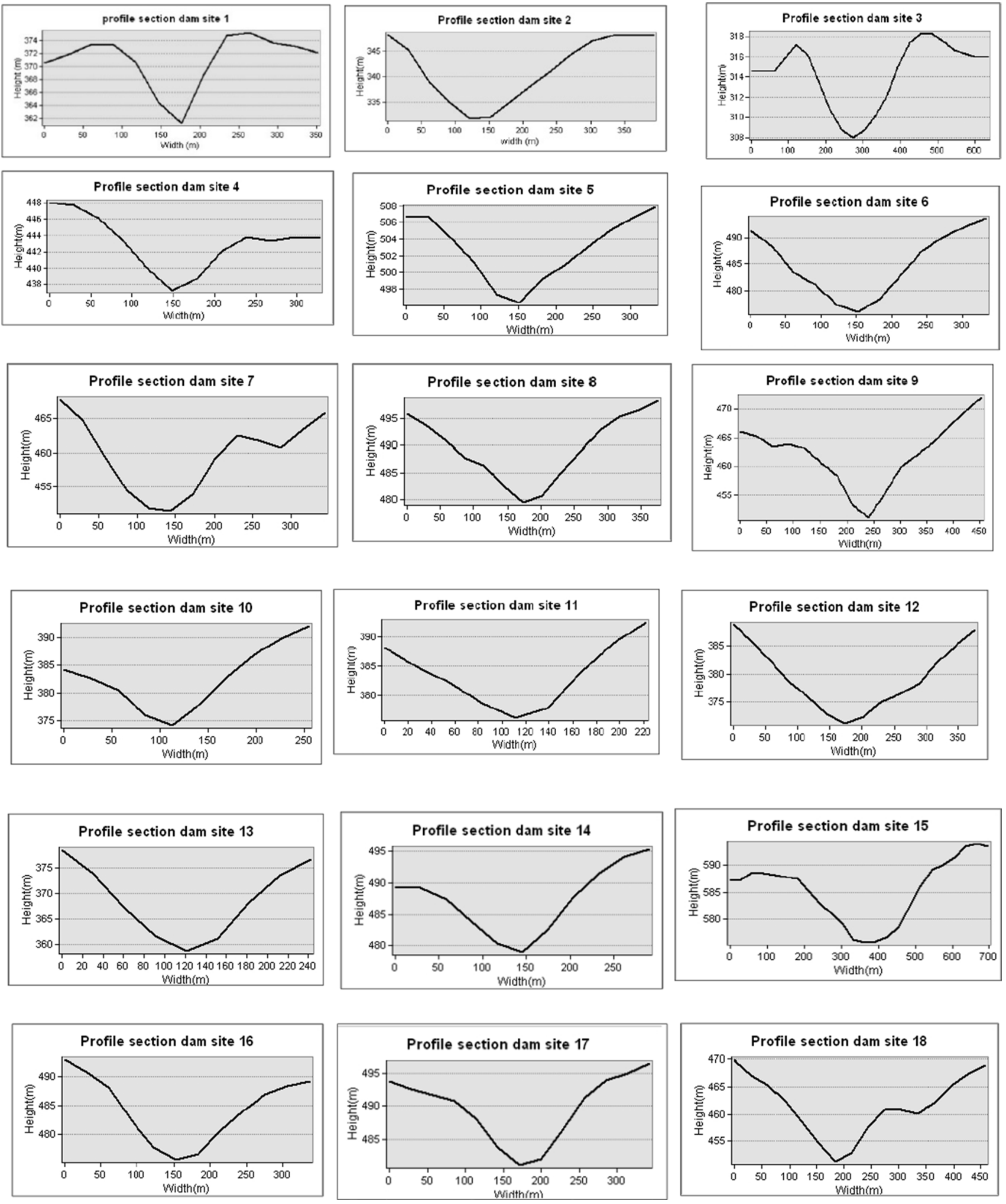

Fig. 11 Cross-sectional profile of all of the identified dam sites 
Table $6 \mathrm{t}$-Test between the field survey and semi-automatic approach

\begin{tabular}{|c|c|c|c|c|}
\hline Dam sites & Width field survey(m) & Width model(m) & Difference $(\mathrm{m})$ & $\%$ difference \\
\hline 2 & 200.78 & 186.43 & 14.35 & 7.1 \\
\hline 6 & 171.89 & 142.24 & 29.65 & 17.2 \\
\hline 8 & 120.09 & 96.23 & 23.86 & 19.9 \\
\hline 10 & 127.3 & 76.23 & 51.07 & 40.1 \\
\hline 13 & 109.11 & 73.03 & 36.08 & 33.1 \\
\hline Average & 228.234 & 184.832 & 43.402 & \\
\hline \multicolumn{5}{|c|}{ t-Test: paired two sample for means } \\
\hline & Variable 1 & & Variable 2 & \\
\hline Mean & 228.234 & & 184.832 & \\
\hline Variance & $12,371.70923$ & & 6599.07302 & \\
\hline Observations & 5 & & 5 & \\
\hline Pearson correlation & 0.712560973 & & - & \\
\hline Hypothesized mean difference & 0 & & - & \\
\hline df & 4 & & - & \\
\hline t Stat & 5.9232 & & - & \\
\hline $\mathrm{P}(\mathrm{T}<=\mathrm{t})$ one-tail & 0.0020 & & - & \\
\hline t Critical one-tail & 2.1318 & & - & \\
\hline $\mathrm{P}(\mathrm{T}<=\mathrm{t})$ two-tail & 0.0040 & & - & \\
\hline t Critical two-tail & 2.7765 & & - & \\
\hline
\end{tabular}

\section{Discussion}

The study factored in ten (10) parameters for SHP dam sites suitability modelling; flow, slope, geology, soil texture, TWI, land use land cover, SPI, elevation, drainage density, and rainfall. The outcome of the integration of these parameters based on GIS and AHP was that the areas of moderate and high suitability accounted for $28.6 \%$ and $27.4 \%$, respectively, for the entire watershed. The result is a preface of the spatiality of the potentials that exist in the watershed and also indicates that the watershed holds significant potentials which if harnessed could provide affordable electricity to the millions of residents living locally within the watershed who are mostly off the grid and lack regular power supply.

Modelling a suitable site for SHP is quite essential, but even more essential is identifying an ideal location based on terrain condition. Most previous studies reviewed did not put this aspect into consideration after creating the Dam suitability site map (DSSM). SHP is typically a run-of-theriver system that takes less time and expenses to construct and integrate into the local setting with low environmental impact as with the case with large dams. Besides steep rivers flowing all year round, another important criterion is the valley width. To mitigate the environmental impacts that usually come with constructing a dam, a narrow valley is ideal. The study made use of contours of $100 \mathrm{~m}$ interval since the watershed is large and they offer good visualization of the watershed terrain. A semi-automatic technique was used to help identify suitable valley width. Eighteen (18) dam sites were identified and evaluated. All dam sites have a good head drop (slope) and are located on third- and fourth-order streams, high drainage density, fall within very high and high suitability class, good geological structure, and rainfall ranging from moderate to very high. Due to multiple thematic layers with different spatial resolutions, the accuracy of the model needed to be checked and validated. Field investigation and measurement were carried to ascertain the veracity of the result and the economic and technical feasibility of constructing dams in these locations. Five potential dam sites were sampled using handheld GPS devices. The field readings were correlated with the desktop model analysis. The result shows the accuracy of the technique is relatively high and thus offers a potential prospect that can help in dam site identification in a large watershed.

With the field investigation, these sites are feasible for locating SHP dams where the entire watershed can benefit primarily for hydropower generation, irrigation farming, and agro-processing thereby boosting the local economy and create job opportunities. The spatiality of SHP potentials should help in rural electrification planning and access to affordable, reliable, sustainable, and modern energy as espoused in Goal 7 of the Sustainable development goals (SDGs). Drawbacks in this study include lack of flow velocity, discharge, and flow duration data from gauge stations in the watershed which would have been used to estimate the energy potential of the water. 


\section{Conclusion}

The study made use of GIS, Remote Sensing and a semiautomatic approach developed to identify and map potentially suitable sites for SHP in the upper Benue River watershed. Ten hydro-physical criteria were utilized and subjected to a series of processing to create a suitability model. Each of the criteria was weighted and ranked using AHP. The composite suitability map produced was divided into five classes: very high, high, moderate, low, and very low. About $7.5 \%$ of the watershed is of the very high suitable class, and $28.6 \%$ of the watershed is moderately suitable. The model was validated by overlaying existing dams, and it revealed that $57.17 \%$ and $28.57 \%$ of the dams are situated in high and moderate suitable areas.

The study developed a semi-automatic method to identify narrow valleys by intersecting contour with stream and suitability index. Over 636 narrow valleys were identified. However, eighteen (18) valley widths were identified to be suitable based on Spatial query operation. The identified dam sites are quite feasible and economically viable for dam construction. The study made use of different thematic data of varied resolution which affected the performance and accuracy of the semi-automatic technique. Hence, very high-resolution data are recommended for future research especially DEM data.

Indeed, GIS is a powerful tool that helps in the synergy of a different dataset to create outputs that allow decisionmakers to make informed decisions as to where is the ideal location for constructing a dam.

Supplementary Information The online version contains supplementary material available at https://doi.org/10.1007/s13201-021-01466-6.

Funding The authors declare that this research did not receive any funds or grants from the public, private or non-governmental organization.

\section{Declaration}

Conflict of interest The authors declare that they have no conflict of interest.

Ethical approval This research is in compliance with the ethical standard and conduct of the journal.

Open Access This article is licensed under a Creative Commons Attribution 4.0 International License, which permits use, sharing, adaptation, distribution and reproduction in any medium or format, as long as you give appropriate credit to the original author(s) and the source, provide a link to the Creative Commons licence, and indicate if changes were made. The images or other third party material in this article are included in the article's Creative Commons licence, unless indicated otherwise in a credit line to the material. If material is not included in the article's Creative Commons licence and your intended use is not permitted by statutory regulation or exceeds the permitted use, you will need to obtain permission directly from the copyright holder. To view a copy of this licence, visit http://creativecommons.org/licenses/by/4.0/.

\section{References}

Abushand E, Alatawi S (2015) Dam site selection using remote sensing techniques and geographical information system to control flood events in Tabuk city. J Waste Water Treat Anal 06(01):1-13. https://doi.org/10.4172/2157-7587.1000189

Adham A, Sayl KN, Abed R, Abdeladhim MA, Wesseling JG, Riksen M, Fleskens L, Karim U, Ritsema CJ (2018) A GIS-based approach for identifying potential sites for harvesting rainwater in the western desert of Iraq. Int Soil Water Conserv Res 6(4):297304. https://doi.org/10.1016/j.iswcr.2018.07.003

Ahmad I, Verma MK (2018) Application of analytic hierarchy process in water resources planning: a gis based approach in the identification of suitable site for water storage. Water Resour Manag 32(15):5093-5114. https://doi.org/10.1007/s11269-018-2135-x

Ajibade TF, Nwogwu NA, Ajibade FO, Adelodun B, Idowu TE, Ojo AO, Iji JO, Olajire OO, Akinmusere OK (2020) Potential dam sites selection using integrated techniques of remote sensing and GIS in Imo state, southeastern, Nigeria . Sustain Water Resour Manag 6(4):57. https://doi.org/10.1007/s40899-020-00416-5

Al-Ruzouq R, Shanableh A, Yilmaz AG, Idris AE, Mukherjee S, Khalil MA, Gibril MBA (2019) Dam site suitability mapping and analysis using an integrated GIS and machine learning approach. Water (switz). https://doi.org/10.3390/w11091880

Becue JP, Degoutte G, Lautrin D (2002) Choice of site and type of dam. Small Dams 17-22

Beven KJ, Kirkby MJ (1979) A physically based, variable contributing area model of basin hydrology. Hydrol Sci Bull 24(1):43-69. https://doi.org/10.1080/02626667909491834

Brimmo AT, Sodiq A, Sofela S, Kolo I (2017) Sustainable energy development in Nigeria: wind, hydropower, geothermal and nuclear. Renew Sustain Energy Rev 74(July):474-490. https:// doi.org/10.1016/j.rser.2016.11.162

Chang K (2014) Intruduction to Geographic Information Systems. McGraw-Hill

Choubin B, Rahmati O, Soleimani F, Alilou H, Moradi E, Alamdari N (2019). Regional Groundwater Potential Analysis Using Classification and Regression Trees. Spatial Modeling in GIS and R for Earth and Environmental Sciences, February, 485-498. https:// doi.org/10.1016/b978-0-12-815226-3.00022-3

Connolly D, Lund H, Mathiesen BV, Leahy M (2010) A review of computer tools for analysing the integration of renewable energy into various energy systems. Appl Energy 87(4):1059-1082. https:// doi.org/10.1016/j.apenergy.2009.09.026

Dai X (2016) Dam site selection using an integrated method of AHP and GIS for decision making support in. Lund University GEM Thesis Series 14. http://lup.lub.lu.se/student-papers/record/88864 48

Duarte M, Nagarajan S, Brixiova Z (2010) Financing of sustainable energy solutions, pp 1-16

Ebhota WS, Tabakov PY (2018) The place of small hydropower electrification scheme in socioeconomic stimulation of Nigeria. Int J Low-Carbon Technol 13(4):311-319. https://doi.org/10.1093/ ijlct/cty038

Fesalbon RMA, Blanco AC (2019) Hydropower dam site selection and visualization using Gis and Rs techniques: a case of marinduque Philippines. Int Arch Photogramm Remote Sens Spatial Inf Sci 42(4/W19):207-214

IEA (2012) Renewable energy techlogies: cost analysis series, hydropower. International Renewable Energy Agency 1(3/5) 44. http:// 
www.irena.org/documentdownloads/publications/re_technologi es_cost_analysis-hydropower.pdf

Ishaku JM, Ankidawa BA, Abbo AM (2015) Groundwater quality and hydrogeochemistry of Toungo area, Adamawa state, North eastern Nigeria. Am J Min Metallurgy 3(3):63-73

Khare V, Khare C, Nema S, Baredar P (2019) Chapter 1 - Introduction to Energy Sources In: V Khare, C Khare, S Nema, PBT-TES Baredar (ed) Elsevier, pp 1-39 https://doi.org/10.1016/B978-012-814881-5.00001-6

Korkovelos A, Mentis D, Siyal SH, Arderne C, Rogner H, Bazilian M, Howells M, Beck H, De Roo A (2018) A geospatial assessment of small-scale hydropower potential in sub-saharan Africa. Energ. https://doi.org/10.3390/en11113100

Lalhmingliana Saha G (2016) Identification of suitable dam site: a survey. Int J Computer Eng Technol 7(5):56-64

Larentis DG, Collischonn W, Olivera F, Tucci CEM (2010) Gisbased procedures for hydropower potential spotting. Energy 35(10):4237-4243. https://doi.org/10.1016/j.energy.2010.07.014

Masoudian M, Theobald S (2011) Influence of land surface topography on flood hydrograph. J Am Sci 7(11):248-256

Moore MG (1972) Moore1.pdf. In Convergence, 5(2): 76-88. http:// www.ajde.com/Documents/learner_autonomy.pdf

Moran EF, Lopez MC, Moore N, Müller N, Hyndman DW (2018) Sustainable hydropower in the 21 st century. Proc Natl Acad Sci USA 115(47):11891-11898. https://doi.org/10.1073/pnas.1809426115

Mura JC, Gama FF, Paradella WR, Negrão P, Carneiro S, de Oliveira CG, Brandão WS (2018) Monitoring the vulnerability of the dam and dikes in Germano iron mining area after the collapse of the tailings dam of fundão (Mariana-MG, Brazil) using DInSAR techniques with terraSAR-X data. Remote Sens 10(10):1-21. https:// doi.org/10.3390/rs10101507

NAEE (2015) NAEE Energy Forum

Omotayo KF, Lasisi MO, Omotayo FS, Engineering B, Polytechnic TF, Ekiti A (2018)Application of geospatial techniques dam site selection in ONDO 3(06): 232-246

Othman AA, Al-Maamar AF, Al-Manmi DAMA, Liesenberg V, Hasan SE, Obaid AK, Al-Quraishi AMF (2020) GIS-based modeling for selection of dam sites in the Kurdistan region, Iraq. ISPRS Int J Geo-Inf. https://doi.org/10.3390/ijgi9040244

Padmavathy AS, Ganesha Raj K, Yogarajan N, Thangavel P, Chandrasekhar MG (1993) Checkdam site selection using GIS approach. Adv Space Res 13(11):123-127. https://doi.org/10. 1016/0273-1177(93)90213-U
Punys P, Dumbrauskas A, Kvaraciejus A, Vyciene G (2011) Tools for small hydropower plant resource planning and development: a review of technology and applications. Energ 4(9):1258-1277. https://doi.org/10.3390/en4091258

Rahmati O, Kalantari Z, Samadi M, Uuemaa E, Moghaddam DD, Nalivan OA, Destouni G, Bui DT (2019) GIS-based site selection for check dams in watersheds: considering geomorphometric and topo-hydrological factors. Sustain (switz). https://doi.org/10.3390/su11205639

REN21 (2012) Renewables 2012 global status report. REN21 Secretariat, Paris. Ren. 21, pp 1-172. http://www.ren21.net/REN21 Activities/GlobalStatusReport.aspx

Roy S, Kumar Bhalla S (2017) Role of geotechnical properties of soil on civil engineering structures. Res Environ 7(4):103-109. https:// doi.org/10.5923/j.re.20170704.03

Samaniego L, Bárdossy A (2006) Simulation of the impacts of land/ cover and climatic change on the runoff characteristics at the mesoscale. Ecol Model 196:45-61. https://doi.org/10.1016/j.ecolm odel.2006.01.005

Saaty TL (1977) A scaling method for priorities in hierarchical structures. J Math Psychol 15(3):234-281. https://doi.org/10.1016/ 0022-2496(77)90033-5

Strahler AN (1957) Quantitative analysis of watershed geomorphology. EOS Trans Am Geophys Union. https://doi.org/10.1029/TR038 i006p00913

UNIDO (2012) UNIDO's small hydropower strategy

UNIDO (2019) World small hydropower development report 2019. World Small Hydropower Development Report, pp 24

Yamato S, Shiibashi T (2012) Small hydropower system. 32(4):258261 https://doi.org/10.14936/ieiej.32.258

Yi C-S, Lee J-H, Shim M-P (2010) Site location analysis for small hydropower using geo-spatial information system. Renew Energy 35:852-861. https://doi.org/10.1016/j.renene.2009.08.003

Zhao B, Zhang L, Xia Z, Xu W, Xia L, Liang Y, Xia D (2019) Effects of rainfall intensity and vegetation cover on erosion characteristics of a soil containing rock fragments slope. Adv Civil Eng. https:// doi.org/10.1155/2019/7043428

Publisher's Note Springer Nature remains neutral with regard to jurisdictional claims in published maps and institutional affiliations. 